American Journal of Environmental Sciences 6 (4): 308-315, 2010

ISSN 1553-345X

(C) 2010 Science Publications

\title{
Impacts of Typhoon on Wave Height at Bangkhuntien Shoreline
}

\author{
${ }^{1}$ Prasertsak Ekphisutsuntorn, ${ }^{1}$ Prungchan Wongwises, \\ ${ }^{2}$ Jiang Zhu and ${ }^{3}$ Suphat Vongvisessomjai \\ ${ }^{1}$ The Joint Graduate School of Energy and Environment, \\ King Mongkut's University of Technology Thonburi, Bangkok, 10140, Thailand \\ ${ }^{2}$ Institue of Atmospheric Physics, Chinese Academic of Sciences, Beijing, PR China \\ ${ }^{3}$ Team Consulting Engineering and Management Co., Ltd., 151 TEAM Building, \\ Nuan Chan Road, Bueng Kum, Bangkok 10230, Thailand
}

\begin{abstract}
Problem statement: In this study, the changing of wave height at Bangkhuntien during a passage of typhoon LINDA was simulated by using the Simulating WAves Nearshore Model (SWAN) version 40.41 . The study domain covered from $99-101^{\circ} \mathrm{E}$ longitude and $12-14^{\circ} \mathrm{N}$ in latitude with resolution of $2.4 \times 2.4 \mathrm{~km}$. The simulation covered 10 days during typhoon LINDA entering into the Upper Gulf of Thailand. The wave height and its changing through the Bangkhuntien shoreline were simulated. The simulated significant wave height by the SWAN model at Petchburi and Ko Srichang buoy stations were compared with the observed significant wave height at these stations for the model verification. Approach: The significant wave height at Bangkhuntien shoreline during a passage of typhoon LINDA was simulated. Results: The results indicated that the significant wave height simulated by SWAN model were in good agreement with the observed data. The average simulated significant wave height at Bangkhuntien shoreline was $0.36 \mathrm{~m}$ and the significant wave height was in a range of 0.1-0.5 m. before typhoon LINDA entering into the Upper Gulf of Thailand. The significant wave height increased to $2.16,2.22$ and $1.66 \mathrm{~m}$ at 26,18 and $5.7 \mathrm{~m}$ sea water depth respectively at the Bangkhuntien shoreline during typhoon LINDA passed. Conclusion: The findings of this study could be useful for the rising wave height, erosive calculation, shoreline protection and coastal zone management when typhoons passed through the Upper Gulf of Thailand.
\end{abstract}

Key words: Significant wave height, LINDA, SWAN, the Upper Gulf of Thailand, Bangkhuntien shoreline

\section{INTRODUCTION}

Bangkhuntien is a district of the Bangkok Municipality under the authority of the Governor of Bangkok Thailand. Bangkhuntien shoreline is the only muddy shoreline in the Bangkhuntien district (Ekphisutsuntorn et al., 2010). This shoreline is located in the Upper Gulf of Thailand (Ekphisutsuntorn et al., 2010) which consists of four river mouths: the Mae Klong, the Tha Chin, the Chao Phraya and the Bang Pakong (Fig. 1). This shoreline is a part of a muddy coastline with mangrove forests. The length of this shoreline is about $5 \mathrm{~km}$ (Ekphisutsuntorn et al., 2010; Kamphuis, 2000). In the past, this coastline was a real inter-tidal area with plenty of mangrove bushes being subject to flooding and allowing the delta to maintain a dynamic equilibrium.

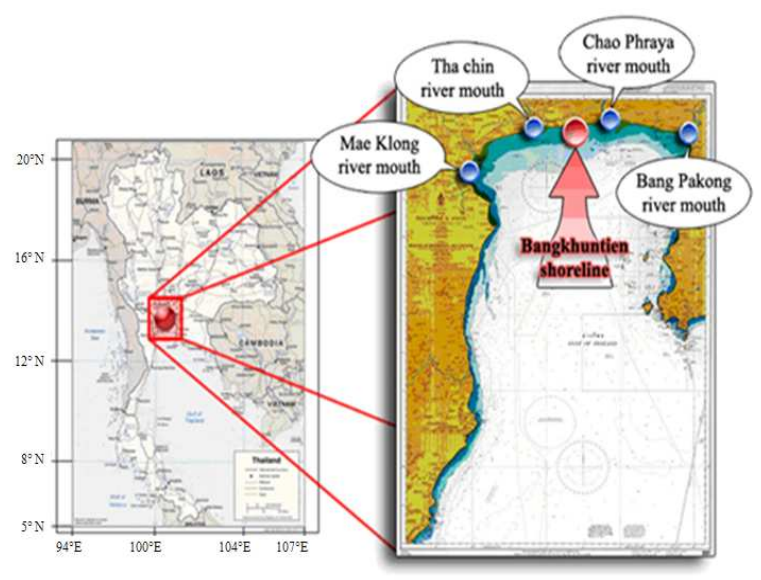

Fig. 1: Map of Thailand and the location of Bangkhuntien shoreline

Corresponding Author: Prasertsak Ekphisutsuntorn, The Joint Graduate School of Energy and Environment,

King Mongkut's University of Technology Thonburi, Bangkok, 10140, Thailand 
Am. J. Environ. Sci., 6 (4): 308-315, 2010

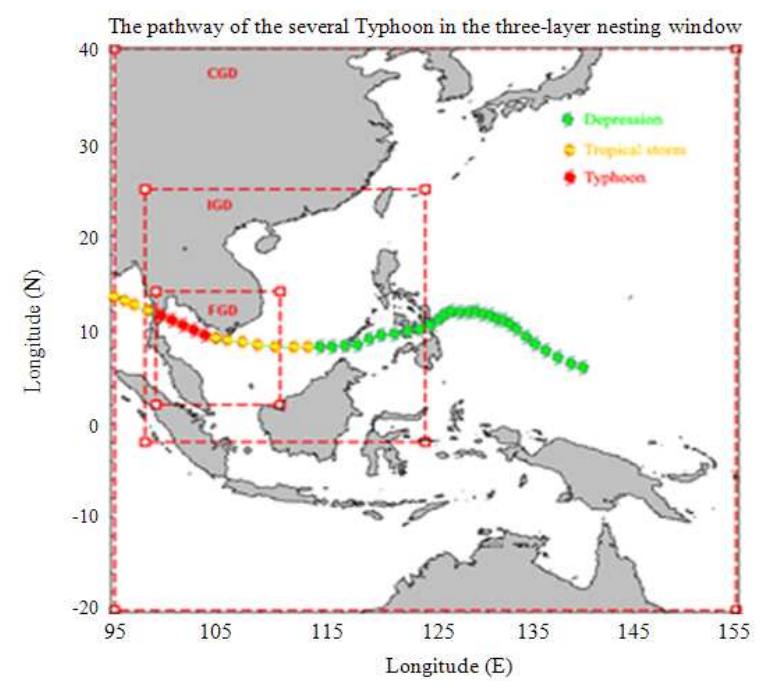

Fig. 2: Based track of typhoon LINDA (Wannawong et al., 2010b)

Its coastline could, at times, be eroded but was built up again, depending on the sediment load and the governing hydraulic conditions (Horikawa and Hattori, 1987; Kamphuis, 2000). The Bangkhuntien coastal zone was degraded and loss of the land occurred due to the erosive forces of the sea. The sediment supply decreased from the river and the attacking of wave and current seem to be the major factors causing the shoreline erosion in this area (Kamphuis, 2000; Jackson, 1999).

Therefore, the characteristics of wave in this area will be studied when typhoon LINDA passed into the Gulf of Thailand from October 31st to November 5th, 1997. The track of typhoon LINDA is shown in Fig. 2 (Aschariyaphotha et al., 2006; Wannawong et al., 2010b). The SWAN cycle III model version 40.51 (Booij et al., 2004) was used for this study.

\section{METERIALS AND METHODS}

The significant wave height at the Upper Gulf of Thailand and Bangkhuntien shoreline must be properly understood by investigating the wave forces on the shoreline. Knowledge of the waves generated by wind and the sediment transported by wave height is very useful in shoreline erosion study in this area. The significant wave height during typhoon LINDA passed into in this area were simulated by the SWAN cycle III model version 40.51 (Booij et al., 2004; Ekphisutsuntorn et al., 2010; Hargreaves and Annan, 2001; Hasselmann et al., 1973; Wannawong et al., 2010a; 2010b; Saleh et al., 2010).
Model description: The SWAN model was developed by Delft University of Technology (Booij et al., 2004; Ekphisutsuntorn et al., 2010; Hargreaves and Annan, 2001; Hasselmann et al., 1973; Wannawong et al., $2010 \mathrm{a} ; 2010 \mathrm{~b})$ and is free for the public domain. It is used by many government authorities, research institutes and consultant worldwide. The feedback has widely indicated the reliability of the SWAN in several experiments and field cases. It is widely used for nearshore wave forecasts around the world.

Based on the wave action balance equation with sources and sinks, the shallow water wave model acronym for Simulating WAves Nearshore (SWAN) is an extension of the deep water third-generation wave models. It incorporates the state-of-the-art formulations for the deep water processes of wave generation, dissipation and quadruplet wave-wave interactions from the WAve Model (WAM) model (Hargreaves and Annan, 2001; Komen et al., 1996). In shallow water, these processes have been supplemented with the formulations for dissipation due to bottom friction, triad wave-wave interactions and depth-induced breaking. The SWAN is fully spectral (in all directions and frequencies) and computes the evolution of wind waves in coastal regions with shallow water and ambient current.

Wind-generated waves have irregular wave heights and periods, caused by the irregular nature of wind. The sea surface elevation, in one point as a function of time, can be described as:

$\eta(t)=\sum_{i} a_{i} \cos \left(\sigma_{i} t+\alpha_{i}\right)$

When:

$\eta=$ The sea surface elevation

$\alpha_{i}=$ The amplitude of the $i^{\text {th }}$ wave component

$\sigma_{i}=$ The relative radian or circular frequency of the $i^{\text {th }}$ wave component in the presence of the ambient current (equal to the absolute radian frequency $\omega$, when no ambient current is presented)

$\sigma_{i}=$ The random phase of the $i^{\text {th }}$ wave component

This is called the random-phase model.

The total energy density at a frequency $f$ is distributed over the directions $\theta$ in $\mathrm{E}(\mathrm{f}, \theta)$, it follows that:

$E(f)=\int_{0}^{2 \pi} E(f, \theta) d \theta$

Based on the energy density spectrum, the integral wave parameters can be obtained. These parameters can 
be expressed in terms of $n^{\text {th }}$ moment of the energy density spectrum:

$$
m_{n}=\int_{0}^{\infty} f^{n} E(f) d f
$$

The total energy of a wave system is the sum of its kinetic energy and its potential energy. The kinetic energy is the part of total energy. The kinetic energy per unit length of wave crest for a linear wave can be found from:

$$
\overline{\mathrm{E}}_{\mathrm{k}}=\frac{1}{16} \rho g \mathrm{H}^{2} \mathrm{~L}
$$

The potential energy per unit length of wave crest for a linear wave is given by:

$$
\overline{\mathrm{E}}_{\mathrm{p}}=\frac{1}{16} \rho g \mathrm{H}^{2} \mathrm{~L}
$$

According to the Airy theory, the total wave energy in one wave length per unit crest width is given by:

$$
\mathrm{E}=\mathrm{E}_{\mathrm{P}}+\mathrm{E}_{\mathrm{k}}=\frac{\rho g \mathrm{H}^{2} \mathrm{~L}}{8}
$$

Total average wave energy per unit surface area, termed the specific energy or energy density, is given by:

$$
\overline{\mathrm{E}}=\frac{\mathrm{E}}{\mathrm{L}}=\frac{\rho g \mathrm{H}^{2}}{8}
$$

Where:

$\mathrm{H}=$ The significant wave height

$\rho=$ The specific gravity of sea water

$\mathrm{g}=$ Gravity acceleration

In this study, the SWAN cycle III model version 40.51 supported by Rijkswaterstaat (as part of the Ministry of Transport, Public Works and Water Management, The Netherlands) was used. The SWAN model (Hasselmann et al., 1973; 1985; 1988) was applied to solve the wave variance spectrum or energy density, wave energy over frequencies and propagation directions.

Study domain: The study domain covered the Upper Gulf of Thailand and the Bangkhuntien shoreline from $99-101^{\circ} \mathrm{E}$ in longitude and $12-14^{\circ} \mathrm{N}$ in latitude with resolution of $2.4 \times 2.4 \mathrm{~km}$ as shown in Fig. 3 .
Data collection: The bathymetry data $(1: 240,000)$ at the Upper Gulf of Thailand were taken from the Hydrological Department of the Royal Thai Navy, wind data $(10 \mathrm{~m}$ height $)$ obtained from the Thai Meteorological Department (TMD) was collected in every $3 \mathrm{~h}$ at Pilot station in 1981-2004 and the observed significant wave height at Petchburi and Ko Srichang buoys in 1996 and 1998 (Fig. 3) were taken from the Geo-Informatics and Space Technology Development Agency (Public Organization) (GISTDA).

Model performance: The simulated performance is evaluated using a goodness of fit measures, namely the Correlation Coefficient (CC):

$$
\mathrm{CC}=\frac{\sum_{\mathrm{i}=1}^{\mathrm{n}}\left[\left(\mathrm{H}_{\mathrm{o}}\right)_{\mathrm{i}}-\left(\overline{\mathrm{H}}_{\mathrm{o}}\right)\right]\left[\left(\mathrm{H}_{\mathrm{m}}\right)_{\mathrm{i}}-\left(\overline{\mathrm{H}}_{\mathrm{m}}\right)\right]}{\sqrt{\sum_{\mathrm{i}=1}^{\mathrm{n}}\left[\left(\mathrm{H}_{\mathrm{o}}\right)_{\mathrm{i}}-\left(\overline{\mathrm{H}}_{\mathrm{o}}\right)\right]^{2}} \sqrt{\sum_{\mathrm{i}=1}^{\mathrm{n}}\left[\left(\mathrm{H}_{\mathrm{m}}\right)_{\mathrm{i}}-\left(\overline{\mathrm{H}}_{\mathrm{m}}\right)\right]^{2}}}
$$

Where:

$\mathrm{H}=$ The significant wave height, the subscripts

'o' and ' $\mathrm{m}$ ' = Represent the observed and model simulated values respectively

Model verification: The SWAN model has been verified with the buoy observational data (the significant wave heights) in 1996 and 1998 at Petchburi and Ko Srichang stations respectively. Figure 4a shows the correlation between the observed significant wave heights and the simulated significant wave heights from the model at Petchburi station in 1996. Figure 4b shows the correlation between the observed significant wave heights at Ko Srichang station and the simulated significant wave heights from the model in 1996.

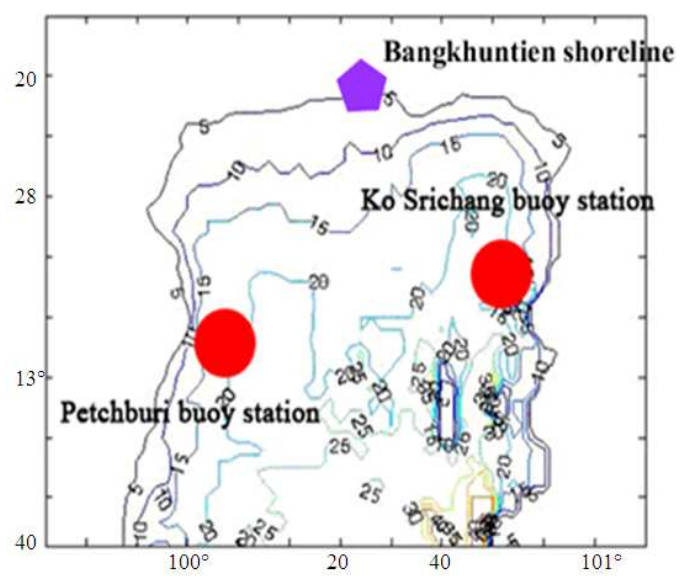

Fig. 3: The bathymetry map of the Upper Gulf of Thailand 
Am. J. Environ. Sci., 6 (4): 308-315, 2010

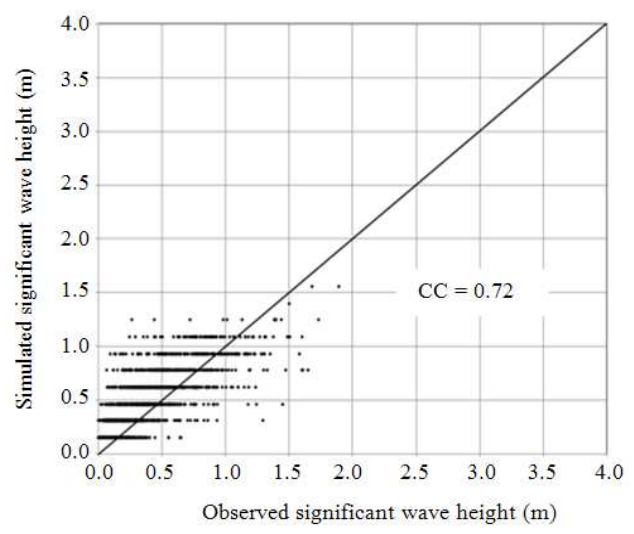

(a)

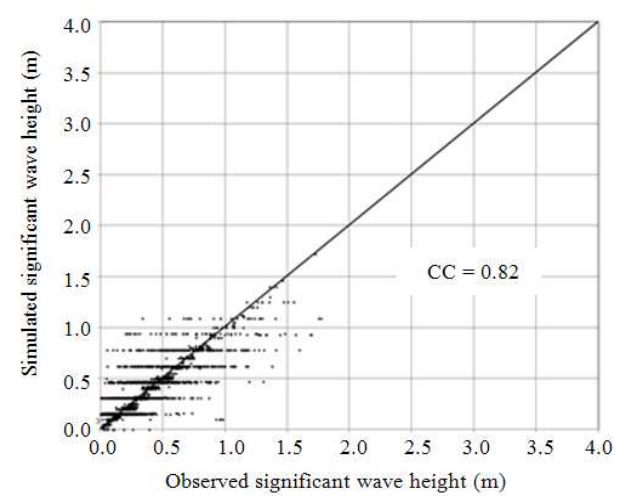

(b)

Fig. 4: Correlation between the observed significant wave heights and the simulated significant wave height in 1996 (a) Petchburi station and (b) Ko Srichang station

The Correlation Coefficient (CC) at Petchburi and Ko Srichang stations were 0.72 and 0.82 respectively. Figure 5a shows the correlation between the observed significant wave heights at Petchburi station and the simulated significant wave heights from the model in 1996. Figure 5b shows the correlation between the observed significant wave heights and the simulated significant wave heights at Ko Srichang station from the model in 1998. The Correlation Coefficient (CC) at Petchburi and Ko Srichang stations in 1998 showed the same value of 0.72 . The comparison of the observed significant wave height at the buoy stations and the simulated significant wave heights presented that the simulation corresponded with the observation.

Model simulation: The SWAN model simulated the significant wave height from 1981-2004 (the data were not collected in 1982 and 1983) at the Upper Gulf of Thailand and the significant wave height from October 31st to November 5th, 1997 (during typhoon LINDA passed) were simulated.

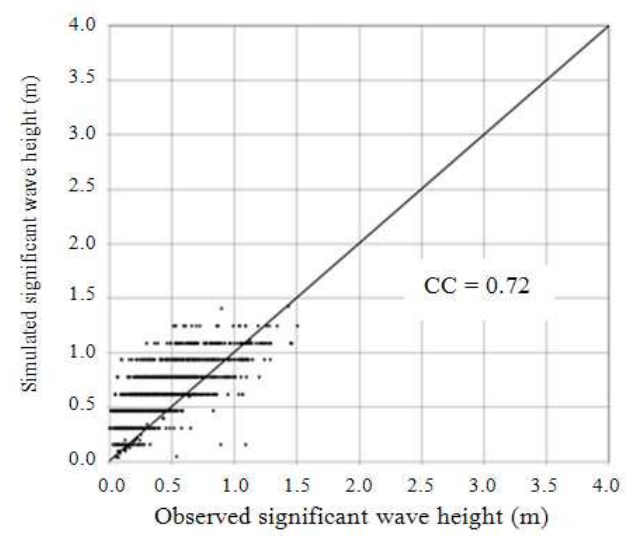

(a)

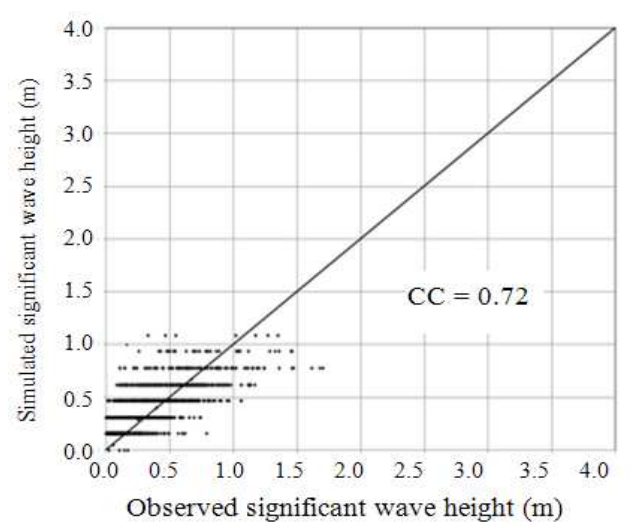

(b)

Fig. 5: Correlation between the observed significant wave heights and the simulated significant wave height in 1998 (a) Petchburi station and (b) Ko Srichang station

\section{RESULTS}

Significant wave height at Bangkhuntien shoreline when typhoon LINDA passed: The application of a two-dimensional model based on the SWAN model to predict the significant wave height at the Upper Gulf of Thailand and Bangkhuntien shoreline before and during typhoon LINDA passed has been described.

Figure 6 presents the significant wave height $(\mathrm{m})$ at the Upper Gulf of Thailand on October 25th 1997 before typhoon LINDA passed. Figure 6a presents the significant wave height at 09:00 on October 25th 1997. The significant wave height at the Upper Gulf of Thailand and Bangkhutien shoreline were about $0.12-0.26$ and $0.12-0.14 \mathrm{~m}$ respectively. Figure $6 \mathrm{~b}$ presents the significant wave height at 12:00 on October 25th 1997. The significant wave height at the Upper Gulf of Thailand and Bangkhuntien shoreline were about $0.06-0.20$ and $0.06-0.10 \mathrm{~m}$ respectively. 
Am. J. Environ. Sci., 6 (4): 308-315, 2010

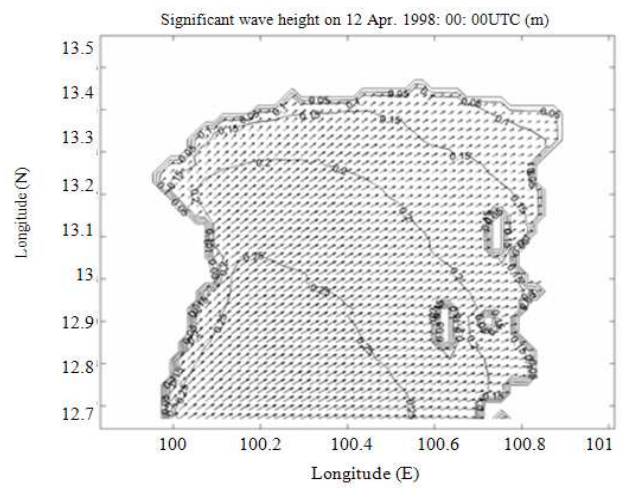

(a)

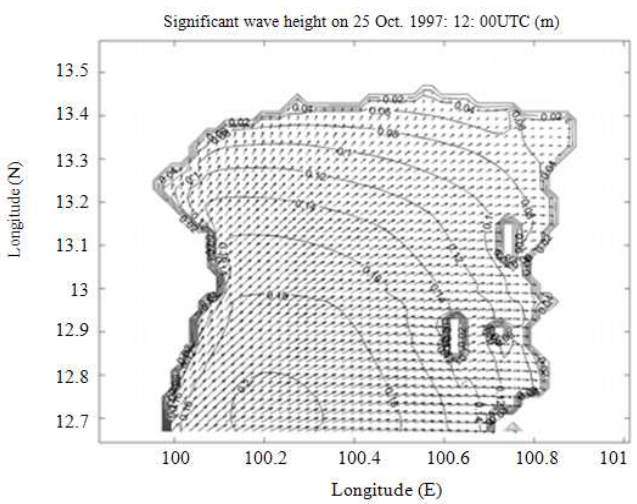

(b)

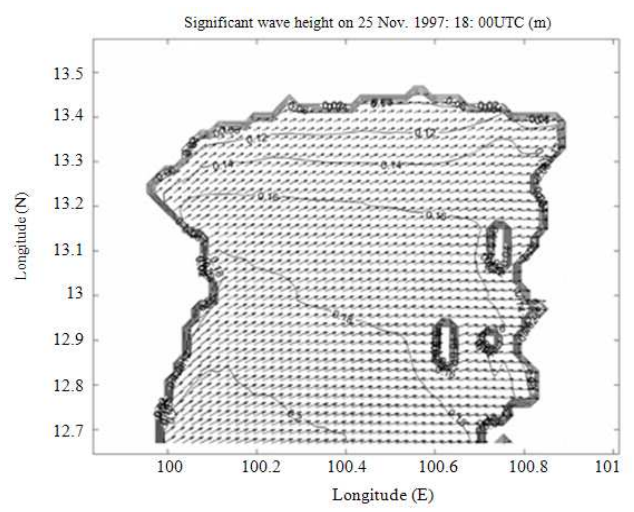

(c)

Fig. 6: Significant wave height (m) at the Upper Gulf of Thailand on October 25th 1997 before typhoon LINDA passed (a) Significant wave height (m) at 09:00 UTC (b) Significant wave height (m) at 12:00 UTC and (c) Significant wave height (m) at 18:00 UTC

Figure $6 \mathrm{c}$ presents the significant wave height at 18:00 on October 25th 1997. The significant wave height at the Upper Gulf of Thailand and Bangkhuntien shoreline were about $0.10-0.20$ and $0.10-0.12 \mathrm{~m}$ respectively.

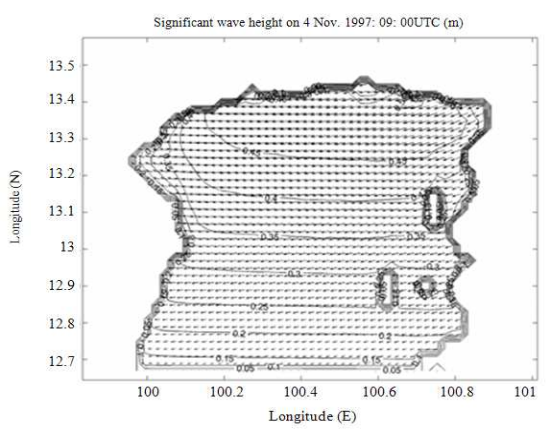

(a)

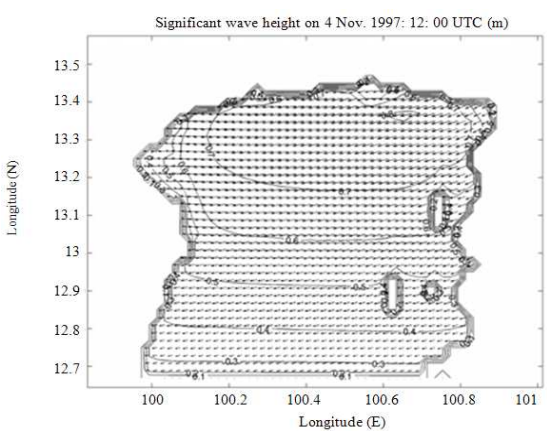

(b)

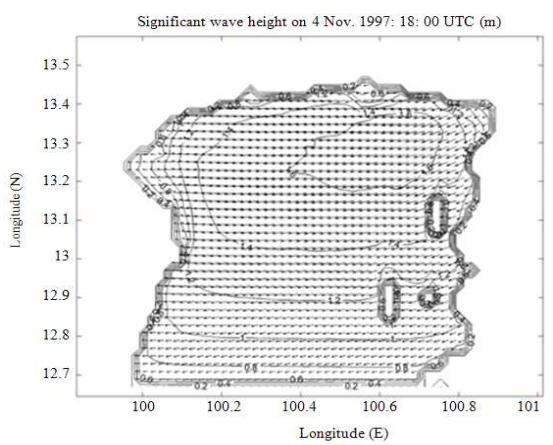

(c)

Fig. 7: Significant wave height at the Upper Gulf of Thailand on November 4th 1997 during a passage of typhoon LINDA (a) Significant wave height (m) at 09:00 UTC (b) Significant wave height $(\mathrm{m})$ at 12:00 UTC and (c) Significant wave height $(\mathrm{m})$ at 18:00 UTC

Figure 7 shows the significant wave height at the Upper Gulf of Thailand on November 4th 1997 during a passage of typhoon LINDA. Figure 7a presents the significant wave height at 09: 00 on November 4th 1997. The significant wave height at the Upper Gulf of Thailand and Bangkhuntien shoreline were about 0.150.45 and $0.15-0.45 \mathrm{~m}$ respectively. Figure $7 \mathrm{~b}$ shows the significant wave height at 12:00 on November 4th 1997. 
The significant wave height at the Upper Gulf of Thailand and Bangkhuntien shoreline were about $0.20-0.70$ and $0.20-0.70 \mathrm{~m}$ respectively. Figure $7 \mathrm{c}$ presents the significant wave height at 18: 00 on November 4th 1997. The significant wave height at the Upper Gulf of Thailand and Bangkhuntien shorelinewereabout1.20-1.80 and 1.40-1.60 m respectively.

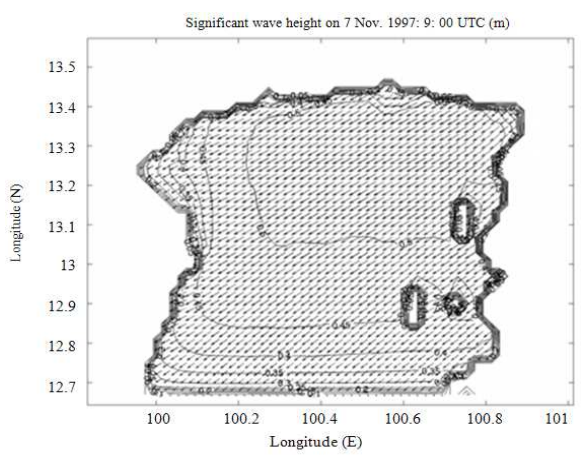

(a)

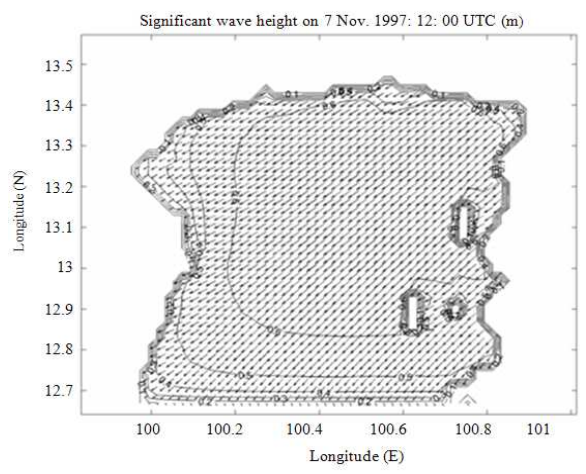

(b)

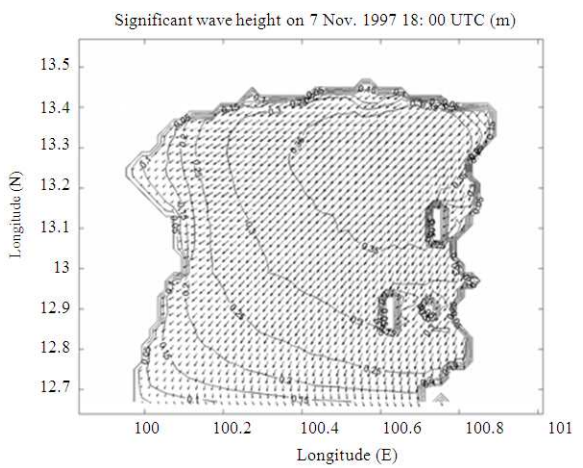

(c)

Fig. 8: Significant wave height at the Upper Gulf of Thailand on November 7th 1997 after typhoon LINDA passed (a) Significant wave height (m) at 09:00 UTC (b) Significant wave height (m) at 12:00 UTC and (c) Significant wave height (m) at 18:00 UTC
Figure 8 shows the significant wave height at the Upper Gulf of Thailand on November 7th 1997 after typhoon LINDA passed. Figure 8a presents the significant wave height at 09:00 on November 7th 1997. The significant wave height at the Upper Gulf of Thailand and Bangkhuntien shoreline were about 0.20-0.60 and 0.20$0.40 \mathrm{~m}$ respectively. Figure $8 \mathrm{~b}$ presents the significant wave height at 12:00 on November 7th 1997. The significant wave height at the Upper Gulf of Thailand and Bangkhuntien shoreline were about 0.40-0.65 and $0.40-0.55 \mathrm{~m}$ respectively. Figure $8 \mathrm{c}$ presents the significant wave height at 18:00 on November 7th 1997. The significant wave height at the Upper Gulf of Thailand and Bangkhuntien shoreline were about 0.150.35 and $0.15-0.30 \mathrm{~m}$ respectively.

\section{DISCUSSION}

The wave height at the Upper Gulf of Thailand was increased due to the accumulated wind energy from the deep sea far away from the shoreline when typhoon LINDA passed over the Gulf of Thailand. Additionally, the wave height was also increased on the seashore and Bangkhuntien shoreline.

\section{CONCLUSION}

Bangkhuntien shoreline was degraded and loss of the land occurred. The attacking wave is one of the major factors of the shoreline erosion, especially at Bangkhuntien shoreline. The SWAN model can be used to simulate the hourly significant wave height at the Upper Gulf of Thailand and Bangkhuntien shoreline.

Table 1: The summary of wave characteristics at Bangkhuntien shoreline (P.III) from 1981-2004

\begin{tabular}{lll}
\hline & Maximum significant & Average significant wave \\
Year & wave height $\left(\mathrm{H}_{\mathrm{S}}\right)(\mathrm{m})$ & 0.47 \\
\hline 1981 & 2.03 & 0.29 \\
1984 & 1.04 & 0.35 \\
1985 & 1.96 & 0.34 \\
1986 & 1.65 & 0.36 \\
1987 & 1.96 & 0.32 \\
1988 & 1.49 & 0.32 \\
1989 & 1.29 & 0.39 \\
1990 & 1.51 & 0.43 \\
1991 & 1.67 & 0.42 \\
1992 & 1.91 & 0.38 \\
1993 & 1.35 & 0.40 \\
1994 & 1.60 & 0.42 \\
1995 & 1.40 & 0.37 \\
1996 & 1.40 & 0.37 \\
1997 & 1.57 & 0.37 \\
1998 & 1.40 & 0.34 \\
1999 & 1.46 & 0.31 \\
2000 & 1.54 & 0.32 \\
2001 & 1.49 & 0.34 \\
2002 & 1.51 & 0.33 \\
2003 & 1.38 & 0.35 \\
2004 & 1.40 & 0.36 \\
Average & 1.55 &
\end{tabular}




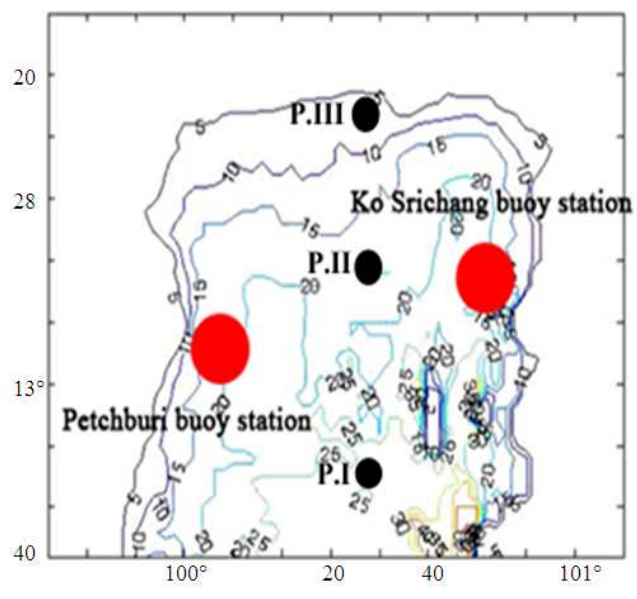

Fig. 9: Representative positions (P.I, P.II, P.III) used for wave height comparison

Table 2: The change of significant wave height during the typhoon Linda passed

\begin{tabular}{llll}
\hline & Depth & $\begin{array}{l}\text { Significant wave } \\
\text { height (m) before } \\
\text { typhoon LINDA passed }\end{array}$ & $\begin{array}{l}\text { Maximum wave } \\
\text { significant height }(\mathrm{m}) \\
\text { during a passage } \\
\text { of typhoon LINDA }\end{array}$ \\
\hline Station & 26 & 0.12278 & 2.16 \\
\hline $\begin{array}{l}\text { Lower point of } \\
\text { the Upper Gulf } \\
\text { of Thailand (P.I) }\end{array}$ & & 0.12278 & 2.22 \\
$\begin{array}{l}\text { Middle point of } \\
\text { the Upper Gulf } \\
\text { of Thailand (P.II) } \\
\begin{array}{l}\text { Bangkhuntien } \\
\text { shoreline (P.III) }\end{array}\end{array}$ & 5.7 & 0.1223 & 1.66 \\
\hline
\end{tabular}

The average significant wave height of the 21 year simulated data at Bangkhuntien shoreline was $0.36 \mathrm{~m}$ as shown in Table 1. The significant wave height increased during typhoon LINDA entering into the Gulf of Thailand and decreased when the storm passed over. The storm affected the significant wave height at the Bangkhuntien shoreline. The significant wave height at different depth of the Upper Gulf of Thailand were 2.16, 2.22 and $1.66 \mathrm{~m}$ at 26 (P.I), 18 (P.II) and $5.7 \mathrm{~m}$ (P.III, Bangkhuntien shoreline) sea water depth respectively in front of the Bangkhuntien shoreline as shown in Fig. 9 and 10 and Table 2. It decreased at water depth of $5.7 \mathrm{~m}$ due to the bottom friction (Booij et al., 2004).

Recommendation: The storm wave is the cause of the shoreline erosion and disaster. The storm wave height and the storm wave energy should be studied. The mechanisms of the erosion and other factors will be considered for the Bangkhuntien shoreline and other shorelines which have the storm wave effects. The effects of storm wave and the shoreline erosion must be simulated under the storm wave height and erosion parameters. The suitable solves and suitable protections will be considered in the future.

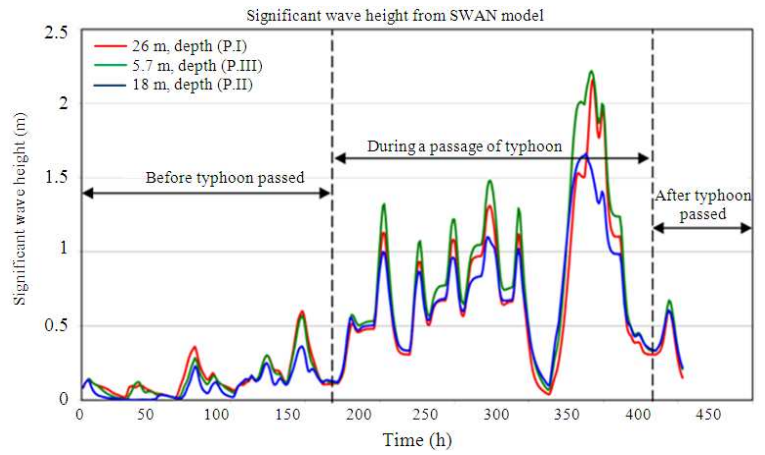

Fig. 10: Significant wave height (m) at the Upper Gulf of Thailand (28 m depth, $18 \mathrm{~m}$ depth and $5.7 \mathrm{~m}$ depth)

\section{ACKNOWLEDGMENT}

This study was supported by the Joint Graduate School of Energy and Environment, King Mongkut's University of Technology, Thonburi. Special thanks are offered to the Hydrological Department of the Royal Thai Navy, the Royal Thai Survey Department (RTSD), the SWAN team and Faculty of Civil Engineering. The authors are grateful to Faculty of Civil Engineering and Geosciences Delft University of Technology for kingly providing the SWAN model. Finally, the authors are greatly indebted to Mr. Michael Willing for helpful comments on English grammar and usage.

\section{REFERENCES}

Aschariyaphotha, N., P. Wongwises, S. Wongwises and U. Humphries, 2006. Phenomena in the Gulf of Thailand when Typhoon Linda 1997 Passed. Proceeding of the 2nd Joint International Conference on Sustainable Energy and Environment, Nov. 21-23, Bangkok, Thailand, pp: 571-576.

Booij, N., I.J.G. Haagsma, L.H. Holthuijsen, A.T.M.M. Kieftenburg and R.C. Ris et al., 2004. SWAN Cycle III version 40.41 user manual. Delft University of Technology. http://fluidmechanics.tudelft.nl/swan/index.htm

Ekphisutsuntorn, P., P. Wongwises, C. Chinnarasri, U.W. Humpries and S. Vongvisessomjai, 2010. Numerical modeling of erosion for muddy coast at Bangkhuntien shoreline, Thailand. J. Environ. Sci., Eng., 2: 230-240.

Hargreaves, J.C. and J.D. Annan, 2001. Comments on Improvement of the short fetch behavior in the Wave Ocean Model (WAM). J. Atmos. Ocean. Tech., 18: 711-715. 
Hasselmann, H., T.P. Barnett, E. Bouws, H. Carlson and D.E. Cartwright et al., 1973. Measurements of wind-wave growth and swell decay during the Joint North Sea Wave Project (JONSWAP). Dtsch. Hydrogr. Z. Suppl., 12: 1-95.

Hasselmann, S., K. Hasselmann, E. Bauer, P.A.E.M. Janssen and G.J. Komen et al., 1988. The WAM model-a third generation ocean wave prediction model. J. Phys. Ocean., 18: 1775-1810.

Hasselmann, S., K. Hasselmann, J.H. Allender and T.P. Barnett, 1985. Computations and parameterizations of the nonlinear energy transfer in a gravity-wave spectrum, Part II: Parameterizations of the nonlinear energy transfer for application in wave models. J. Phys. Ocean., 15: 1378-1391.

Horikawa, K. and M. Hattori, 1987. The nearshore environment research center project. Proceedings of a Specialty Conference on Advances in Understanding of Coastal Sediment Processes, American Society of Civil Engineers, May 12-13, New Orleans, LA., USA., pp: 756-771.

Jackson, N.L., 1999. Evaluation of criteria for predicting erosion and accretion on an estuarine sand beach, Delaware Bay, New Jersey. J. Estuar. Coast., 22: 215-223.
Kamphuis, J.W., 2000. Introduction to Coastal Engineering and Management. 1st Edn., World Scientific Publishing, Singapore, ISBN: 10: 9810244177, pp: 472.

Komen, G.J., L. Cavaleri, M. Donelan, K. Hasselmann and S. Hasselmann et al., 1996. Dynamics and Modeling of Ocean Waves. 1st Edn., Cambridge University Press, UK., ISBN: 10: 0521577810, pp: 556.

Saleh, E., J. Beliku, T. Aung and A. Singh, 2010. Wave characteristics in Sabah waters. Am. J. Environ. Sci., 6: 219-223.

Wannawong, W., U.W. Humphries, P. Wongwises, S. Vongvisessomjai and W. Lueangaram, 2010a. Numerical analysis of wave and hydrodynamic models for energy balance and primitive equations. J. Math. Stat. Sci., 6: 140-150.

Wannawong, W., U.W. Humphries, P. Wongwises, S. Vongvisessomjai, 2010b. Three steps of oneway nested grid for energy balance equations by wave model. J. Compt. Math. Sci., 5: 23-30. 